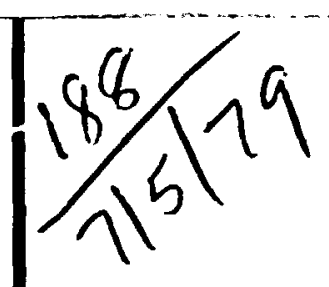

\title{
DR. 2.811
}

ORNL-5531

\section{MASTER}

Transuranium Processing Plant Report of Production, Status, and Plans for the

Period January 1, 1978-September 30, 1978

\author{
L. J. King \\ J. E. Bigelow \\ E. D. Collins
}


Dist. Category UC-4

Contract No. w-7405-eng-26

CHEMICAL TECHNOLOGY DIVISION

TRANSURANIUM PROCESSING PLANT REPORT OF PRODUCTION, STATUS, AND PIANS FOR THE PERIOD JANUARY 1, 1978 - SEPmEMBER 30, 1978

L. J. King, J. E. Bigelow, anà E. D. Collins

Date Published - June 1979

OAK RIDGE NATIONAL LABORATORY

Oak Ridge, Tennessee 37830

o: perated by

UNION CARBIDE CORPORATION

for the

DEPART:IENT OF ENERGY 
Reports previously issued in this series:

ORaI-4376 Period Ending June 30, 1968

ORer-4428 Period Ending December 31, 1968

ORW-4447 Period Ending June 30, 1969

ORW-4540 Period Ending Decewber 31, 1969

ORaL-4588 Period Endiny June 30, 1970

Oral-4666 Period Ending Necember 31, 1970

ORarl-4718 Period Ending viune 30, 1971

ORNL-4767 Period Ending December 31, 1971

ORenL-4833 Period Ending June 30, 1972

ORaL-4884 Period Ending Derember 31, 1972

ORAL-49::? Period Ending June 30, 1973

ORNL-4965 Period Ending December 31, 1973

ORan-4991 Period Ending June 30, 1974

ORaL-5034 Period Ending December 31, 1974

ORUL-5094 Pexicd Ending June 30, 1975

ORNL-5145 Period Ending December 31, 1975

ORNL-5216 Feriod Ending June 30, 1976

ORNL-5305 Period Ending December 31, 1976

ORAL-5358 Period Ending June 30, 1977

ORNL-5415 Period Ending December 31, 1977 
Contears

SUMARY ........................... v

1. INTRODUCTION ...................... I

2. PRCLESSING SUIAYRY AND PRODUCTION ESTIMATE $\ldots \ldots$. . . . . 1

2.1 Processing Sumary .................. 2

2.2 Irradiation and Processing Proposals .......... 3

2.3 Estimates of the Availability of Transuranium Elements . . ?

3. PROCESSES AND EQLIPHENT . . . . . . . . . . . . . . . 8

4. CALIfORNIUM NEUTRON SOURCES ................. . . 9

4.1 Sources Fabricated During January 1978 - September 1978 . ?

4.2 Used Sources Returned to TRU . . . . . . . . . . . . . 3

5. SPECIAL PROSECTS .................. . . 13

5.1 Purification of Americium-243 . . . . . . . . . 13

5.2 Enrichment of Plutonium-244 ............ 13

5.3 Production of californium-254 ............. 14

6. DECAY AND NEUTRON CROSS-SECTION DATA . . . . . . . . 15

7. REFERENCES . . . . . . . . . . . . . . . . . . . . . . 
This is the 21st report in a series that is being issued to inform the heavy-element comunity of the status and future production plans of the Transuranium Element Production Program at Ural. This report covers a nine-month period, whereas previous reports have been issued semiannually and subsequent reports wiil be issued annually. It is appropriate to extend the period covered by each report because the progran has become more stable and production estinates are not subject to significant changes.

During the pexiod January 1, 1978, through September 30, 1978, we obtained transuraniu elements from 13 irradiated HFIR targets; products recovered are listed in Table 2.1. In addition, the final purifications of three batches of ${ }^{248} \mathrm{Cm}$ were completed. Forty-two product shipments were made from TRU; recipients and the awounts of nuclides shipped are listed in Table 2.2. Six KFIR targets were fabricated; each contained approximately $2 \mathrm{~g}$ nf ${ }^{243} \mathrm{Am}$ and $7.5 \mathrm{~g}$ of curium.

During the next 18 montr.s, we expect to obtain totals of $78 \mathrm{mg}$ of ${ }^{249} \mathrm{Bk}, 835 \mathrm{mg}$ of ${ }^{252} \mathrm{Cf}, 3.0 \mathrm{mg}$ of ${ }^{253} \mathrm{Es}$ (in a mixture of isotopes), $425 \mathrm{\mu g}$ of high-purity ${ }^{253} \mathrm{Es}$, and $1.7 \mathrm{pg}$ of ${ }^{257} \mathrm{Fm}$; we also expect to make available $150 \mathrm{mg}$ of high-purity ${ }^{248} \mathrm{Ch}$.

During this report period, the precision of the fast-neutron counting system in the TURF californium Facility was improved sufficiently to permit assay of the ${ }^{252} \mathrm{Cf}$ content in pellets, sources, and shipping packages. The TURF counter will be used especially for assaying packages containing large amounts of ${ }^{252} \mathrm{Cf}$ (up to $50 \mathrm{mg}$ ) because the counter system is heavily shielded and personnel using the system will receive relatively small exposures.

Pellets for neutron sources NSP -10; and NSD-105 were fabricated, although the encapsi: > iions were no: completed. A total of 100 netiron sources have been fabricated previously at TRU. The original and current contents $\left({ }^{252} \mathrm{Cf}\right.$ and $\left.{ }^{248} \mathrm{Cm}\right)$ of existing sources and the individuals to whom these sources are currently loaned are listed in Table 4.1. Three used sources were returned to TRU during this report period. Pive sources were reassigned and three, containing 19,288 , and $2041 \mathrm{ug}$ of ${ }^{252} \mathrm{Cf}$, respectively, are available. 
BLANK PAGE 
Special projecis included (1) completing production of several grams of ultra-high-purity ${ }^{243} \mathrm{Am}$, (2) final purification of $54.3 \mathrm{mg}$ of highpurity ${ }^{244} \mathrm{Pu}$, and (3) preparation of $418 \mathrm{pg}$ of ${ }^{254} \mathrm{Cf}$ from $39-\mathrm{hr}{ }^{254 \mathrm{~m}} \mathrm{Es}$ that was produced by irradiaticn of $14 \mathrm{\mu g}$ of ${ }^{253} \mathrm{is}$. 


\section{INTRODIJCTION}

This is the $21 s t$ report in a series that is being issued to inform the heary-element community of the status and the future production plans of the Transuranium Element Production Frogram at ORN. The informatior: presented will enable users of the products to obtain maximum service from the production facilities.

Between 1968 and 1977, 20 reports were issued semiannually. This report covers the nine-month period from January 1, 1978, through September 30 , 1978, and subsequent reports will be issued annually. It is appropriate to extend the time period covered by each report because the projram has become stable and estimates of production plans and schedules for the near future are not subject to significant changes. However, long-range plans can still be markedly influenced by feedback from researchers and other users of transuranium elements.

Operations during this report period are sumaricec, and the amounts of materials obtained and shipped are listed. Proposed processing schedules and anticipated yields of various producss in the near future are outlined. The original and currert contents $\left({ }^{252} \mathrm{Cf}\right.$ and $\left.{ }^{248} \mathrm{Cm}\right)$ of existing neutron sources made at TRU, as well as the individuals to whom these sources are currently loaned, are tabulated. Special projerts to produce ultra-highpuirity ${ }^{243} \mathrm{Am}$, enriched ${ }^{244} \mathrm{Pu}$, and enriched ${ }^{254} \mathrm{Cf}$ are described. values of nuclear parameters that were used as input data for the calculations of production rates for transuranium elements, along with a listing of the parameters used to calculate the specific activities of the isotopes that are of interest to TRU, are included in the appenciix of ORNL-5415. 1

\section{PROCESSING SUMMARY AND PRODUCTION ESTIMATE}

The isotopic cone intrations of the various transuranium elements are not constant but are functions of irradjation histories and decay times. We have selected one isotope of each element to use in making material balances for the isotcpic mixtures normally handled. Except in special 
instances, ${ }^{242} \mathrm{pu},{ }^{243} \mathrm{Am},{ }^{244} \mathrm{~cm},{ }^{249} \mathrm{Bk},{ }^{252} \mathrm{Cf},{ }^{253} \mathrm{Es}$, and ${ }^{257} \mathrm{Fm}$ are the isotopes used for tracing tine corresponding elements. Throughout this report, we are discussing mixtures of isotopes unless we indicate otherwise.

\subsection{Processing Sumary}

Between January 1, 1978, and September 30, 1978, the following operations were accomplished:

1. One chemical procersing campaijn (No. 54) was made to obtain transuranium alements frua 13 HFIR-irradiated targets plus rework material. Products from this campaign are listed in Table 2.1 .

2. Four batches of ${ }^{248} \mathrm{Cm}$ were purified. The first three batches (Nos. 21, 22 , and 23) contained a total of $138 \mathrm{mg}$ of high-purity ${ }^{248} \mathrm{Cm}$ with a specitic ac Łivity of approximately $2 \times 10^{7}$ alpha cpm/mg; this material had been separated from the parent ${ }^{252}$ cf during earlier report periods. ${ }^{1-3}$ The fourth batch (No. 24) was $45 \mathrm{mg}$ of lesser-quality ${ }^{248} \mathrm{Cm}$ with a tenfold higiner specific activity (approximately $2 \times 10^{8}$ alpha cpm/mg) due to a higher concentration of ${ }^{244} \mathrm{Cm}$. The material of Batch No. 24 was obtained from rework solutions which had been accumulated during californium purification operations throughout the past three years.

3. Forty-two product shipments were made. Re ipients and the amounts of nuclides shipped are listed in Table 2.2 .

4. Six HFIR targets were fabricated. Each target contained approximately $2 \mathrm{~g}$ of americium $\left(100 \mathrm{~g}^{243} \mathrm{Am}\right)$ and $7.5 \mathrm{~g}$ of curium in the form of mixed americium curium oxide-aluminum pellets that had been pressed to 807 of the theoretical density of the pellet core. The isotopic composition of the curium in the t.urgets was approximately $37.7 \%{ }^{244} \mathrm{Cm}, 0.48{ }^{245} \mathrm{Cm}$, $53.08{ }^{246} \mathrm{~cm}, 1.48{ }^{247} \mathrm{~cm}$, and $7.58{ }^{248} \mathrm{~cm}$. 
Table 2.1. Amounts of materials obtained in the major carpaign in the Transuranim Processing Plant during the poriod January 1, 1978 - September 30, 1978

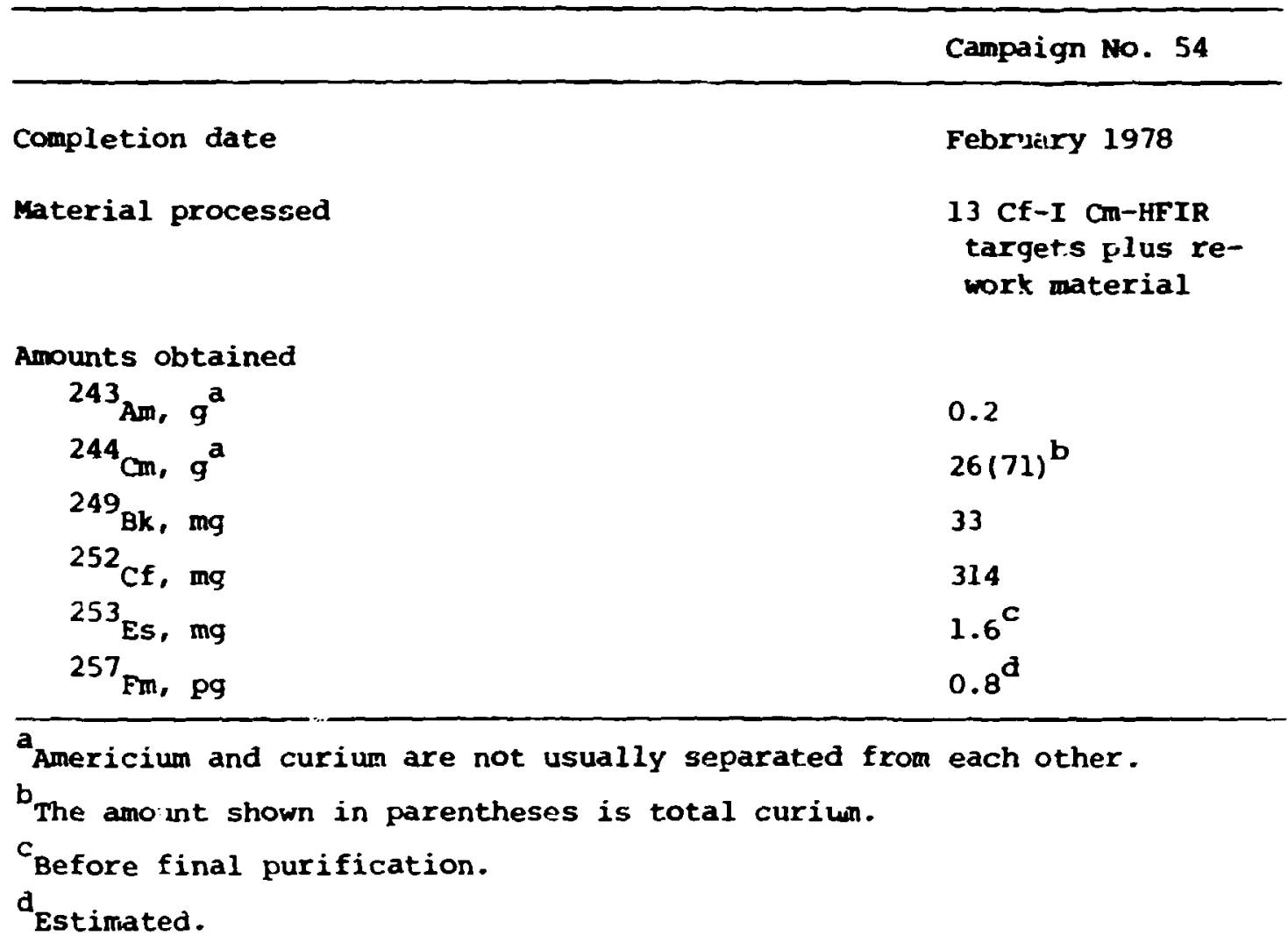

\subsection{Irxadiation and Processing Proposals}

The level of transuranium element production is expected to continue at a rate of two processing campaigns per year. A long-term projection of the capability of the TRU-HFIR complex to produce the "yardstick" isotope ${ }^{252} \mathrm{cf}$ was described in a previous report in this series. ${ }^{4}$ Table 2.3 outlines the estimated production of transcurium elements from a series of likely processing campaigns that are scheduled through March 1980 . Projections for the remainder of FX 1980 and FY 1981 are based on current trends. 
Table 2.2. Distribution of heavy elements from the Transuranium Pricessing Plant during the period January 1, 1978 - September 30, 1978

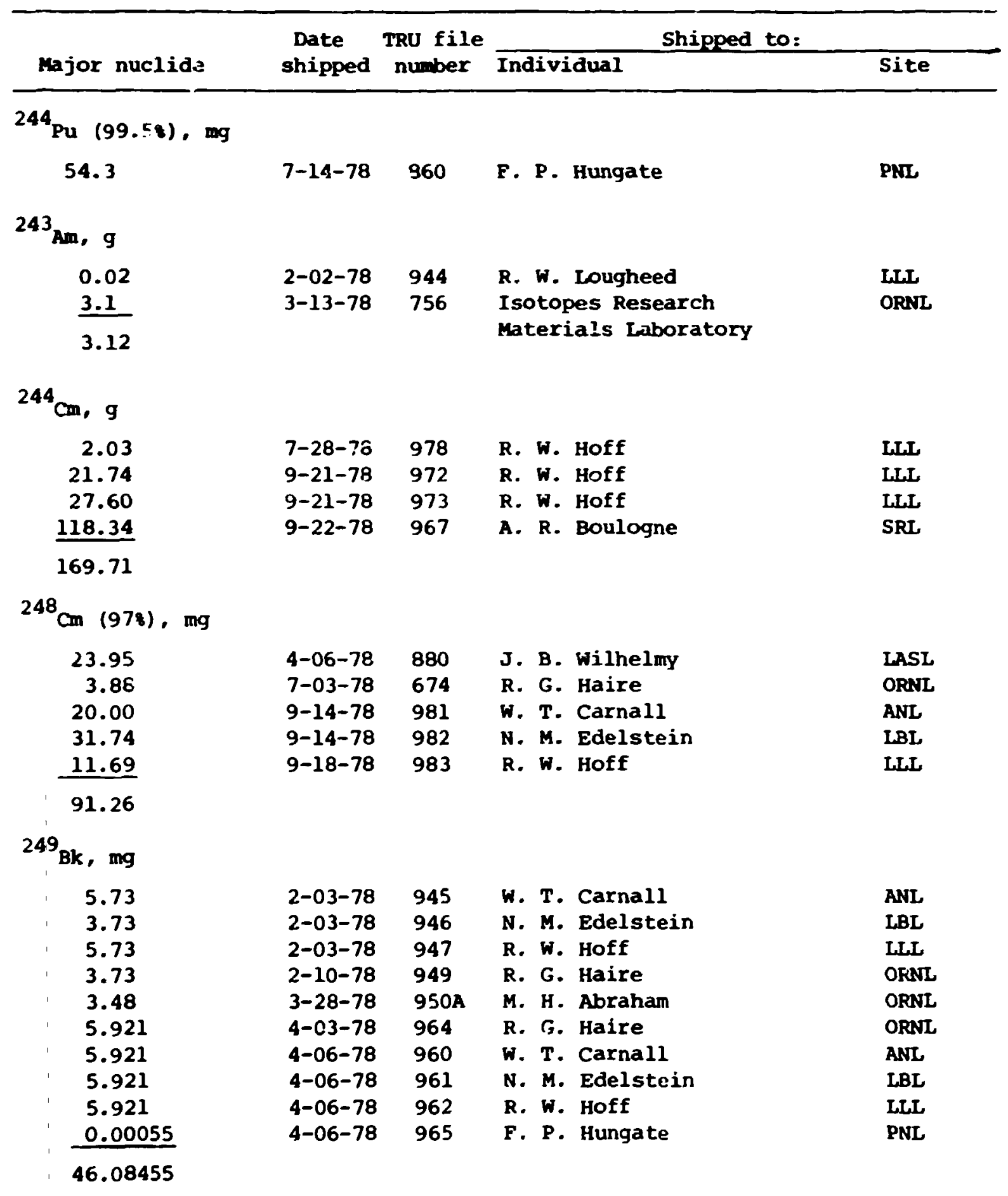


Table 2.2. (continued)

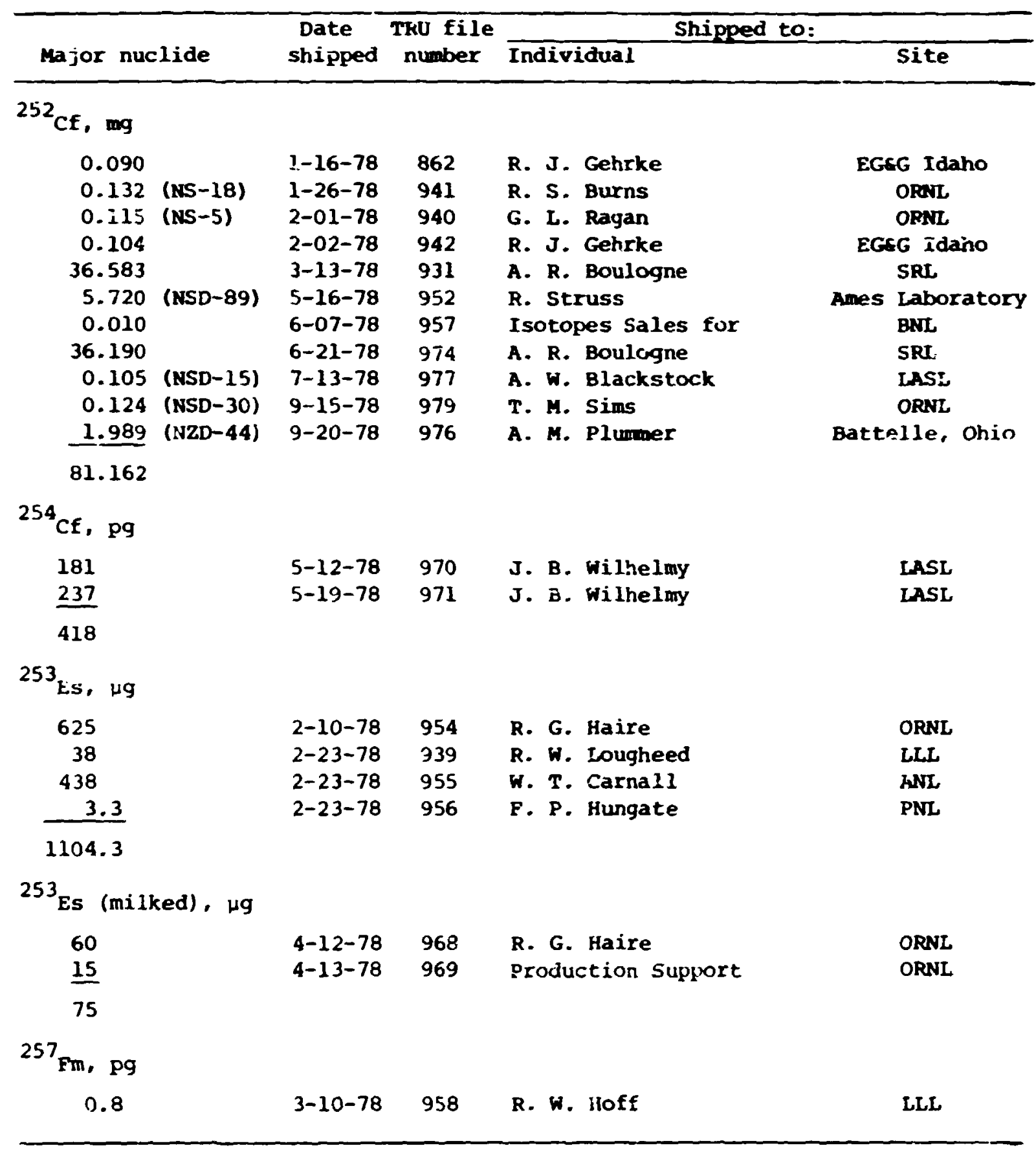


Table 2.3. Estimar:ed future production of transcurium elementa

\begin{tabular}{|c|c|c|c|c|c|c|c|c|}
\hline \multirow[b]{3}{*}{ Period } & \multirow[b]{3}{*}{ Processing campaign } & \multirow{2}{*}{\multicolumn{2}{|c|}{ Products }} & \multirow{2}{*}{\multicolumn{2}{|c|}{ of campaigns }} & \multicolumn{2}{|c|}{${ }^{252} \mathrm{ce}$ production ${ }^{b}$} & \multirow[b]{3}{*}{$\begin{array}{c}\text { Date } \\
\text { produste } \\
\text { available }\end{array}$} \\
\hline & & & & & & \multirow{2}{*}{$\begin{array}{l}\text { During } \\
\text { the } \\
\text { period } \\
\text { (mg) }\end{array}$} & \multirow[b]{2}{*}{$\begin{array}{l}\text { Cumula- } \\
\text { tive } \\
\text { (mg) }\end{array}$} & \\
\hline & & $\begin{array}{c}249 \mathrm{Bk} \\
\text { (mg) }\end{array}$ & $\begin{array}{r}252 \mathrm{Cf} \\
\text { (mg) }\end{array}$ & $\begin{array}{c}253 \mathrm{Es}^{2} \\
(\mu \mathrm{g})\end{array}$ & $\begin{array}{c}257 \mathrm{gm} \\
(\mathrm{pg})\end{array}$ & & & \\
\hline Trrough Septeinber & 1978 & & & & & & $3206^{b}$ & \\
\hline $\begin{array}{l}\text { October } 1978- \\
\text { Sept amber } 1979\end{array}$ & $\left\{\begin{array}{cc}10 & \text { Ci. }: \text { Cm-HFIR targets } \\
3 & \text { TRU Cm-HFIR targats }\end{array}\right\}$ & 30 & 330 & $800(75)$ & 0.6 & 330 & 3436 & February 1979 \\
\hline $\begin{array}{l}\text { October } 1979- \\
\text { March } 1980\end{array}$ & $\left\{\begin{array}{ll}8 & \text { Cf-I Cm-HFIR targets } \\
5 & \text { TRU Cm-HFIR targets }\end{array}\right\}$ & 48 & 505 & $2220(350)$ & 1.1 & EOJ & 3941 & February 1980 \\
\hline $\begin{array}{l}\text { April } 1980- \\
\text { September } 1980\end{array}$ & & & & & & 300 & 4241 & \\
\hline FY 1981 & & & & & & 600 & $484 !$ & \\
\hline
\end{tabular}

amounts from initial separation. Amcurts "milked" from californium product fraction after decay perivd are given in parentheses.

${ }^{b}$ californium produced in SRP ilradiations is not included in production totals. A total of $720 \mathrm{mg}$ was recovered from 164 SRP slugs and 21 SRP tubes processed between November 1970 dind January 1973. 


\subsection{Estimates of the Availability of Transuranium Elements}

The amounts of transcurium elements expected from each campaign are shown in Table 2.3. During the next 18 months, we expect to recover a total of $78 \mathrm{mg}$ of ${ }^{249} \mathrm{Bk}, 835 \mathrm{mg}$ of ${ }^{252} \mathrm{Cf}, 3.0 \mathrm{mg}$ of ${ }^{253} \mathrm{Es}$ !in a mixture of isotopes), $425 \mathrm{\mu g}$ of higli-purity ${ }^{253} \mathrm{Es}$, and $1.7 \mathrm{pg}$ of ${ }^{257} \mathrm{Fm}$. The Iollowing steps were used to forecast the anounts: (1) calculation of the amounts of transcurium elements in each group of targets at the time of reacto- discharge by means of our computer code, (2) addition cf the assumed amounts of rework feed, and (3) applicatiun of the assumed chemical yield factors and net decay factors for the assumed recovery times to the arounts of total feed (targets plus rework). The assumed chemical yields and recovery times are based on past performance data, and the most recently revised values are given i, Table 2.3 of ORNL-5305. 2

Curium-248, a valuable research material, is formedisy aipha decay of 252 Cf. On September 30,1978 , TRU held the inventory of purified californium shown in Table 2.4. At appropriate times, a group of packages and/or unneeded pellets or neutron sources will be processed to separate the californium and curium. The curium thus obtained is consider 1 to be high-purity ${ }^{248} \mathrm{~cm}$; the typical isotopic composition is $978{ }^{248} \mathrm{Cm}, 3{ }^{246} \mathrm{Cm}$, and $0.018{ }^{244} \mathrm{~cm}$. The ${ }^{246} \mathrm{Cm}$ is produced by the decay of ${ }^{250} \mathrm{cf}$, which is present in the californium. We expect to make available $80 \mathrm{mg}$ of the highpurity ${ }^{248} \mathrm{Cm}$ in FY 1979 ar $370 \mathrm{mg}$ in early FY 1980.

Table 2.4. Inventory of purified californium-252

\begin{tabular}{|c|c|c|c|}
\hline \multicolumn{2}{|c|}{ Container } & \multicolumn{2}{|c|}{ Content on Sepcember 30,1978} \\
\hline Type & Number & ${ }^{252} \mathrm{cf}$ (mg) & $248 \mathrm{Cm}$ (mg) \\
\hline Stored packages & 34 & 945 & 365 \\
\hline${ }^{252}$ Cf pellets & 12 & 31 & 19 \\
\hline \multirow[t]{2}{*}{ Neutron sources } & 80 & 156 & 238 \\
\hline & & 1132 & 622 \\
\hline
\end{tabular}




\section{PROCESSES AND EQUIPHENT}

Duxing this report period, the precision of the fast-neutron counting system in the TURF Californium Facility was improved sufficiently to :ermit assay of the ${ }^{252} \mathrm{Cf}$ content in pellets, sources, and shipping packages. Previously, the counting system was used only to make estimations of the ${ }^{252}$ Cf assays because there was occasionally a large variation in successive counts made on the same package.

A series of counting experiments was made that involved four successive counts of each package or source as it was rotated $90^{\circ}$ between counts. The standard deviation among the four counts was frequently in the range 1 to 21. These experiments indicated conclusively that the centroid of the neutron-emitting material $\left({ }^{252} \mathrm{Cf}_{2} \mathrm{O}_{2} \mathrm{SO}_{4}\right)$ was not located at the axis of rotation of the source or shizping package. Thus the centroid moved closer or farther away from the detector as the source was rotated. The amount of :ccentricity indicated by the variability in the count rate was calculated to be within the diameter of the scurce package.

A mathematical model of an eccentric source location was derived and a program was written for a programmable calculator to compute the standard deviation based on the model. When processed by the program, the standard deviations for sets of four successive counts $\left(90^{\circ}\right.$ apart) fell in the range 0.13 to 0.508 . This is about the same precision as the fast-neutron system which is located at TRU and which is used to assay the ${ }^{252} \mathrm{Cf}$ content of all sources and packages shipped from TRU or transferred between TRU and TURF.

The TURF counter was calibrated over the useful range and will be used in preference to the counter at TRU for assaying packages containing large amounts of ${ }^{252}$ Cf (up to $50 \mathrm{mg}$ ) that are transferred between the buildings. This will redice the amount of personnel exposures incurred in making the assays because the TURF counter system is more heavily shielded. 


\section{CALIFORNIUN NEUTRON SOURCES}

Some of the recovered californium is incorporated into neutron sources, which are subsequently loaned to researchers. Data for existing neutron sources fabricated at TRU are listed in Table 4.1. Most of the sources were fabricated into one of the four standard models illustrated in Fig. 4.1 of ORNL- $4921^{5}$ and are designated in the table by a three-letter prefix. Nonstandard sources are designated simply "NS- ." The three-letter prefix indicates whether the source is singly or doubly encapsulated and whether it is fabricated from type 304L stainless steel or from zircaloy-2. The characteristics of standara source capsules are listed in rable 4.2 of ORNL-492l.

\subsection{Souzces Fabricated During January 19:8 - September 1978}

The pellets for sisurces NSD-104 and NSD-105 were fabricated during this report period. However, the encapsulations were not completed.

\subsection{Used Sources Returned to TRU}

A number of neutron sources are returned to TRU when the projects for which the; are requested are completed or when replacement sources are ordered to make up for decay of the ${ }^{252} \mathrm{Cf}$. The returned sources are available for reassignment until the appropriate time for reprocessing to recover the ingrown ${ }^{248} \mathrm{~cm}$. During this report period, three sources were returned to TRU, five were reassigned, and three containing 19, 288, and $2041 \mu \mathrm{g}$ of ${ }^{252} \mathrm{Cf}$, respectively, remain in the "available" categury and are so designated in Table 4.1. 
Twhe 4.1. Dete for murros cources prepered at iv

\begin{tabular}{|c|c|c|c|c|c|c|}
\hline \multirow[b]{3}{*}{ sonson } & \multirow{3}{*}{$\begin{array}{c}\text { Dete of } \\
\text { eallicerios }\end{array}$} & \multirow{3}{*}{$\begin{array}{c}252 \mathrm{ce} \\
\text { content of } \\
\text { colluretes } \\
\text { (m) }\end{array}$} & \multicolumn{2}{|c|}{$\begin{array}{c}\text { content is of } \\
2 / 30 / \pi\end{array}$} & \multirow{2}{*}{\multicolumn{2}{|c|}{ on lones co: }} \\
\hline & & & $252 \mathrm{ce}$ & $24 a$ & & \\
\hline & & & $(\omega)$ & $(\log )$ & Iadividen & site \\
\hline$=-1^{\circ}$ & $e-20-c$ & 316 & 22 & $\mathbf{b}$ & x. I sulneh & ond \\
\hline$x=-2$ & $0-23-\infty$ & 275 & 19 & b & $c$ & \\
\hline$=3$ & $5-13-69$ & $v 90$ & -8 & b & C. I. Glenevon & anv \\
\hline$=-4$ & $7-09-69$ & $\mathbf{\infty}$ & 79 & 767 & C. F. meens: & LASI \\
\hline$=-5^{a}$ & $4-14-69$ & 1.009 & 96 & 909 & C. L. negan & ond \\
\hline$=6$ & $11-21-69$ & 767 & 73 & 642 & a. W- Boef & LII \\
\hline$=-7$ & $1-21-7 J$ & $\pi$ & 61 & 675 & F. R. Cuet in & ond-2ho \\
\hline $5-6$ & $12-17-69$ & 1,039 & 184 & $1,5 \pi$ & H. Bexger & Nur \\
\hline $\operatorname{mos}$ & $6-17-70$ & 1,720 & 180 & 1.461 & w. o. Wogman & Fin \\
\hline$=5-10$ & $1-11-70$ & 113 & 12 & $\mathbf{b}$ & J. P Belegne & Lasi \\
\hline $15-12$ & $3-10-70$ & e & 1 & b & R. P. Rull1000d & Lasi \\
\hline uss-12 & $6-30-70$ & 1,860 & 215 & 1,576 & R. W. Hote & LLI \\
\hline$\triangle S D-13$ & $3-19-71$ & 4,649 & 646 & 3,817 & H. O. Manlove & LASt \\
\hline ws5-14 & $6-29-70$ & 4.615 & 531 & 3,895 & D. C. Stewart & ANS \\
\hline$m s-15^{\circ}$ & $6-25-70$ & $\mathbf{8 4}$ & 99 & 729 & A. W. Blackstock & LASL \\
\hline$n s s-17$ & $0-31-71$ & 4,886 & 764 & 3,931 & L. W. Dahilke & $\begin{array}{l}\text { Sondie- } \\
\text { Livernore }\end{array}$ \\
\hline$=-10^{d}$ & $6-24-70$ & 960 & 110 & 811 & a. S. Burns & oner. \\
\hline $\cos$ & $6-26-70$ & 493 & 57 & 416 & J. E. Bigelow & Ons-Tnu \\
\hline$m-20$ & $7-01-70$ & 630 & 73 & 532 & J. E. Powe. 1 & $\begin{array}{l}\text { Sondia- } \\
\text { wer nexico }\end{array}$ \\
\hline$-2-21$ & $10-21-70$ & 18 & 2 & $\mathbf{b}$ & F. Cross & PNL \\
\hline$n s-22$ & $9-10-70$ & 13 & 2 & $\mathbf{b}$ & J. E. Bigelon & anl-rnu \\
\hline SD-24 & $10-15-70$ & 6 & 1 & $b$ & J. E. Rusheon & orar \\
\hline $105-25$ & $11-09-70$ & 58 & 7 & $\mathbf{b}$ & F. J. Mctenthaler & opest \\
\hline $150-26$ & $2-11-71$ & 14 & 2 & $b$ & H. O. Nenlove & LASL \\
\hline $150-27$ & $1-29-71$ & 2.528 & 339 & 2,007 & L. C. Welson, Jr. & $\begin{array}{l}\text { Hew Brurawick } \\
\text { Laboratory }\end{array}$ \\
\hline $1050-26$ & $2-12-71$ & 11 & 1 & $\mathbf{b}$ & E. E. Hick: & Mocky Fiats \\
\hline $100-29$ & $9-10-71$ & 11,393 & 1.794 & 9,153 & S. 6. Snow & $x-12$ \\
\hline $100-30$ & $3-31-71$ & 876 & 123 & 718 & T. A. Sim & ONOLL. \\
\hline 31 & $11-23-71$ & 1,731 & 288 & 1,377 & $c$ & \\
\hline$x-34$ & $11-23-71$ & 1,924 & 320 & 1,530 & W. G. Spear & HEDL \\
\hline m-35 & $11-23-71$ & 1,896 & 315 & 1,500 & M. Clark & $\begin{array}{c}\text { University of } \\
\text { costa ntce }\end{array}$ \\
\hline$m=36^{d}$ & $3-23-71$ & 2,070 & 280 & 1.699 & Y. D. Warker & Ecec Idato \\
\hline $100-37$ & $9-04-71$ & 9,838 & 1,543 & 7.910 & n. .. Perkins & PmL. \\
\hline $\cos 0-30$ & $6-16-71$ & 102 & 15 & b & H. O. Mmlove & LASL \\
\hline $18-39$ & $11-07-71$ & 942 & 155 & 751 & v. Splegel & was \\
\hline$\infty x-40$ & $4-27-72$ & 1,154 & 214 & 696 & 9. P. Dalagna & LASL \\
\hline$=0-41$ & $11-08-71$ & 5,117 & 841 & 4,078 & C. .T. Emert & BAPL \\
\hline
\end{tabular}


Iuble 4.1. (continend)

\begin{tabular}{|c|c|c|c|c|c|c|}
\hline \multirow[b]{2}{*}{ source } & \multirow{2}{*}{$\begin{array}{l}\text { Date of } \\
\text { cailbration }\end{array}$} & \multirow{2}{*}{$\begin{array}{c}252 \mathrm{ct} \\
\text { content at } \\
\text { calibretion } \\
\text { (ug) }\end{array}$} & \multicolumn{2}{|c|}{$\cos ^{\operatorname{cont}} \sin ^{\circ}$} & \multicolumn{2}{|c|}{ Ca 100 en: } \\
\hline & & & (mg) & $(u g)$ & Individoel & site \\
\hline $150-42$ & $11-02-71$ & 4,434 & 725 & 3.537 & c. Z. Emert & art \\
\hline$=50-43$ & $4-20-12$ & 4.839 & 894 & 3.762 & c. J. Emere & mapt \\
\hline$x=0-4$ & $5-15-72$ & 10.129 & 1,962 & 8.076 & A. M. Plumer & $\begin{array}{c}\text { actelle. } \\
\text { onts }\end{array}$ \\
\hline uso-4s & $8-18-71$ & 1.776 & 275 & 1.431 & X. L. Suinth & $\operatorname{par}$ \\
\hline $1050-16$ & $4-23-72$ & 629 & 117 & 489 & H. O. Menlove & Last \\
\hline $15 D-47$ & $7-14-71$ & $\approx$ & 30 & 162 & P. L. Johnswon & nound \\
\hline $150-48$ & $7-14-71$ & 194 & 29 & 157 & A. C. Englend & oover. \\
\hline Mso-49 & $7-14-71$ & 199 & 30 & 161 & ¿- J. Eech & XAPL \\
\hline $105-50$ & $8-23-71$ & 138 & 21 & 111 & S. G. Carpenter & MNL-wists \\
\hline $\operatorname{RsO}-51$ & $11-02-71$ & 365 & 60 & 291 & z. L. Benjanin & $\begin{array}{l}\text { United wucleer } \\
\text { Intuseries }\end{array}$ \\
\hline $150-52$ & $9-02-71$ & 280 & 44 & 225 & E. D clayton & PNDL \\
\hline NSD-53 & $10-25-71$ & $1.0: 1$ & 178 & A39 & I. J. Esch & DAPE \\
\hline$x-54$ & $1-19-73$ & 3,187 & 717 & 2,356 & v. Spiegel & $\operatorname{los}$ \\
\hline MSD-S5 & $4-19-72$ & $\bullet$ & 1 & $B$ & L. J. Esch & rAPL \\
\hline w50-56 & $4-19-72$ & 124 & 23 & 96 & M. M. Bretucher & Nor \\
\hline KSD-57 & $4-14-72$ & 973 & 179 & 757 & J P. Baiagina & LASL \\
\hline$m 20-58$ & $5-15-72$ & 10.849 & 2,041 & 8,399 & $c$ & \\
\hline NS $-59^{d}$ & $7-13-72$ & 53 & 10 & $\mathbf{b}$ & G. E. Henson & LASL \\
\hline NSL-60 & $4-11-72$ & 21 & 4 & b & P. F. Haymood & ORenL-DOSAR \\
\hline x5D-61 & $1-19-73$ & 5,225 & 1.175 & 3,862 & L. J. Esch & xaPL \\
\hline MSS-62 & $3-27-73$ & 3.755 & 886 & 2,736 & J. E. Bigelow & ORerL-THU \\
\hline $\mathrm{NSD}-63$ & $4-21-72$ & 047 & 157 & 658 & H. $O$. Menlove & LASL \\
\hline NSD-64 & $7-19-73$ & 193 & 49 & 137 & H. O. menlove & LASL \\
\hline N5-65 & $7-09-73$ & 114 & 29 & 81 & L. Green & BAPL \\
\hline NSD-66 & $9-02-73$ & 3,449 & 892 & 2,438 & J. E. Powell & $\begin{array}{l}\text { Sandia, } \\
\text { Wew nexico }\end{array}$ \\
\hline NSD -67 & $6-07-76$ & 33.501 & 7.365 & 5.852 & H. G. Rieck & PNLL \\
\hline MSL - 68 & $6-c 7-76$ & 16,838 & 9.185 & 7.298 & H. G. Rieck & a: \\
\hline NSD.69 & $6-07-76$ & 16.775 & 9,151 & 7,271 & H. G. Rieck & PNoL \\
\hline NSD-70 & $6-10-76$ & 22.748 & 12,436 & 9,834 & H. G. Rieck & Pm. \\
\hline MSD -71 & $7-15-75$ & 21.319 & 11,951 & 8,934 & H. G. Aleck & PRL \\
\hline $1450-72$ & $7-15-76$ & 16602 & 9,307 & 6.957 & H. G. Rieck & $P \cos$ \\
\hline$A S D-73$ & $9-11-73$ & 13,545 & 3,607 & 9,478 & G. I. Gleason & onau \\
\hline NSD-74 & $9-11-73$ & 4,416 & 1,176 & 3,090 & G. I. Gleason & conu \\
\hline NS- 75 & $10-01-73$ & 1.919 & 518 & 1,336 & A. J. Xloepping & LLL \\
\hline 150-76 & $3-09-74$ & 434 & 131 & 289 & P. L. Johnson & round \\
\hline NSD- 77 & $3-09-74$ & 433 & 131 & 288 & P. C. Johnson & Nound \\
\hline NSD -78 & $3-09-74$ & 429 & 130 & 285 & P. L. Johnson & nound \\
\hline
\end{tabular}




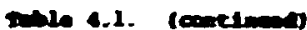

\begin{tabular}{|c|c|c|c|c|c|c|}
\hline \multirow[b]{3}{*}{ source } & \multirow{3}{*}{$\begin{array}{c}\text { Drte of } \\
\text { calisuretion }\end{array}$} & \multirow{3}{*}{ 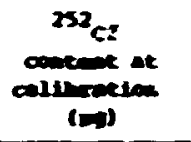 } & \multicolumn{2}{|c|}{ mencen } & \multirow{2}{*}{\multicolumn{2}{|c|}{ on 100 : }} \\
\hline & & & ${ }^{232} \alpha$ & 20 & & \\
\hline & & & & $(a)$ & Imdethel & site \\
\hline$=-79$ & $10-02-74$ & 1.650 & 379 & 1.021 & v. Splogl & $\infty$ \\
\hline$=0$ & $(-0)-74$ & 5.506 & 1.92: & 3,057 & c. J. Ext & $\mathbf{m r}$ \\
\hline$=0-1$ & $6-a 3-74$ & 6.301 & 2.309 & 4.115 & C. J. Eute & $\operatorname{mr}$ \\
\hline$=-\infty 2$ & $5-19-75$ & 14.250 & 5.904 & 7,973 & G. Toneser & $m x$ \\
\hline$=0$ & $9-24-75$ & 11.703 & 5.306 & 6.139 & C. Theler & $m$ \\
\hline$=5 \rightarrow 4$ & $9-30-75$ & 12.674 & 5,775 & 6.579 & C. Teselex & $\operatorname{mex}$ \\
\hline$=-\infty$ & $10-22-73$ & 12.101 & 5.630 & 6.239 & C. Tweolur & $\operatorname{san}$ \\
\hline$\omega-\infty$ & $11-17-75$ & 2.620 & $1.2 \times$ & 1.320 & v. splesel & $\operatorname{ses}$ \\
\hline$=\infty-\infty$ & $10-13-75$ & 22.307 & 10.111 & 11.516 & c. I. Clameser & ספan \\
\hline$=0-\infty$ & $0-20-73$ & 9.520 & 4.240 & 5.2013 & a. L. Ollrich & and \\
\hline$\infty-\infty$ & $4-23-75$ & 12.590 & 3,110 & 7,134 & - serwes & 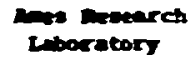 \\
\hline$-20-90$ & $1-16-73$ & 0.87 & $<1$ & b & J. A. Saite & $\infty$ \\
\hline$=0-1$ & $9-20-73$ & 15 & 7 & b & L. J. Each & $\operatorname{ran}$ \\
\hline$=-92$ & $6-24-x$ & 2.960 & i.634 & 1.200 & v. spiesel & $\infty$ \\
\hline$=0-93$ & $1-29-74$ & 500 & 167 & $3 \times 6$ & J. P. Ealespen & Last \\
\hline $150-9$ & $3-0,-77$ & 1,540 & 1,026 & 4 & F. N. Clike & pardite \\
\hline$=0-95$ & $3-9-71$ & 1.537 & 1.021 & 92 & r. n. clikman & nurden \\
\hline$=n-96$ & $1-0,-71$ & 1.196 & 793 & 302 & P. W. Clikeman & purdae \\
\hline$=09-97$ & $3-05-77$ & 1.39 & 930 & 440 & 7. W. Cilkemen & nurdae \\
\hline$\omega 00-90$ & $9-30-73$ & 0.000 & 3.645 & 4.153 & J. L. Pollex & $=0$ \\
\hline$m s 0-99$ & $9-21-77$ & 713 & 547 & 160 & C. A. Strand & 20 \\
\hline$=0-101$ & $5-24-76$ & 24.136 & 13,035 & 10,587 & J. E. Pow:: & $\operatorname{sen}_{\min }$ \\
\hline $\operatorname{sen}-\alpha t-167^{\circ}$ & $5-26-71$ & 3.975 & 500 & 3.230 & J. E. Nuthen & and \\
\hline
\end{tabular}

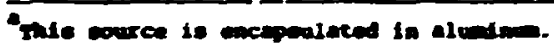

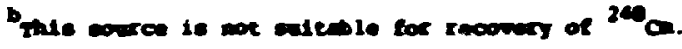

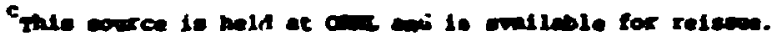

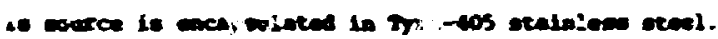

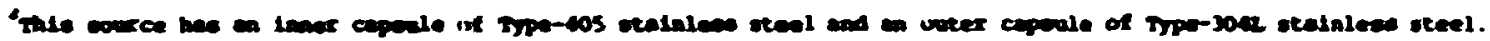

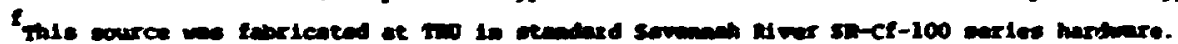




\section{SPECIAL PROJECTS}

The primary functions of TRU are (1) to fabricate targets for irradiation in the HFIR to produce transuraniem elements and (2) to isolate and purify transuranium elements for use by research workers. However, the facilities that are available ${ }^{6}$ are also used for a variety of other purposes, such as nonroutine production, special preparations, and special irradiations in HFIR. In each case, a unique service can be provided to assist a research program at ORNL or another site.

\subsection{Purification of Americium-243}

The project to prepare a multigram amount of highly purified ${ }^{243} \mathrm{Im}$ (for use in neutron cross-section studies, for capture gamm studite, and as an analytical standard) was completed during this report period. ${ }^{1}$ Ion exchange techniques were used to reduce the concentration of ${ }^{244} \mathrm{Cr}$. in the $243 \mathrm{Am}$ to less than $1 \mathrm{l}, \mathrm{pm}$. Approximately $32 \mathrm{~g}$ of ${ }^{243} \mathrm{Am}$ was purified and then converted to the oxide form by calcining the oxalate. Another batch, containing $2 \mathrm{~g}$ of ${ }^{243} \mathrm{Am}$, was purified further using new equipment and special care to prevent recontamination, this product contained $\leq 25 \mathrm{pph}$ of $244 \mathrm{~cm}$.

\subsection{Enrichment of Plutonium-244}

A project to enrich the ${ }^{244} \mathrm{Pu}$ concentration in approximately $100 \mathrm{mg}$ of plutonium for use in biomedical studies was completed during this report period. During April 1977, the plutonium was irradiated in the HFIR to burn out the lighter isotopes; it was then chemically processed to isolate the irradiated plutonium. ${ }^{3}$ The isolated plutoniun was stored to await decay of ${ }^{246} \mathrm{Pu}$ (half-life $=10.85$ d). A final purification run (nitrate anion exchange) was made during this report period. The final product, containing $54.3 \mathrm{mg}$ of ${ }^{244} \mathrm{Pu}$, read only $2 \mathrm{mR} / \mathrm{hr}$ at contact. The specific alpha activity of the product was about three times that of pure ${ }^{244} \mathrm{Pu}$ but only $1 / 2200$ of that of pure ${ }^{239}$ Pu; most of the excess activity came from the ${ }^{242} \mathrm{Pu}$, which was present in a concentration of 0.68 . The complete 
isotopic analysis is shown in Table 5.1, along with contzibutions to alpha activity.

Table 5.1. Isotopic analysis of enriched plutonium-244

\begin{tabular}{llc}
\hline Nuclide & Atom & $\begin{array}{c}\text { Percentage } \\
\text { of alpha }\end{array}$ \\
\hline${ }^{238} \mathrm{Pu}$ & $0.000033^{\mathrm{a}}$ & 11.11 \\
${ }^{239} \mathrm{Pu}$ & $0.0021^{\mathrm{a}}$ & 2.60 \\
$240_{\mathrm{Pu}}$ & 0.0016 & 7.20 \\
${ }^{241} \mathrm{Pu}$ & 0.0013 & 0.07 \\
$242 \mathrm{Pu}$ & 0.572 & 43.62 \\
$244 \mathrm{Pu}$ & 99.423 & 35.40 \\
\hline${ }^{2}$ Values adjusted to agree with observed alpha pulse-height analysis.
\end{tabular}

\subsection{Production of Californium-254}

Californium-254 was produced by the electron-capture decay 10.078 branching) of $39-\mathrm{hr}{ }^{254} \mathrm{~m}$ Es. The ${ }^{254}$ Es was produced by irradiation of $14 \mathrm{ug}$ of isotopically pure ${ }^{253} \mathrm{Es}$ for $40 \mathrm{hr}$ in a hydraulic rabbit facility of the HPIR. When ${ }^{254} \mathrm{Cf}$ is produced in this manner, it is sufficiently enhanced with respect to ${ }^{252}$ cf to permit studies of the spontaneous fission properties of ${ }^{254} \mathrm{Cf}$ without interference from the fissions of ${ }^{252} \mathrm{Cf}$.

The irradiated rahbit (cooled for $8 \mathrm{hr}$ ) was transferred to TRU Cave B by means of the hydraulic transfer system from the HFIR basin. The rabbit was dissolved and chemically processed, in a manner similar to previous operations, ${ }^{7}$ to isolate the ${ }^{253-254 m}$ Es from other actinide - in product, and activation product elements. A high-pressure ion exchal.gr u: was made to separate the einsteinium from the initial californium daughters. inen, after a five-day interval, a second high-pressure ion exchange run was nade to separate the newly ingrown californium. Product from the second run is the premium ${ }^{254} \mathrm{Cf}$; however, the product from the first run was also of suitable quality. The isotopic compositions of the californium products are listed in Table 5.2. The assay of 0.0914 atom ${ }^{254} \mathrm{Cf}$ in the produr: 
Table 5.2. Californium-254 proauct compositions

\begin{tabular}{llllll}
\hline & $-\frac{\text { First run fraction }}{\text { Nuclide }}$ & Atom & $\begin{array}{l}\text { Percentage } \\
\text { of fissions }\end{array}$ & Atom & $\begin{array}{l}\text { Percentage } \\
\text { of fissions }\end{array}$ \\
\hline${ }^{249} \mathrm{Cf}$ & 7.2 & $5 \times 10^{-8}$ & $\leq 2.4$ & 20 \\
$250 \mathrm{Cf}$ & 86.4 & 2.7 & 299.91 & 1.10 \\
${ }^{251} \mathrm{Cf}$ & 3.6 & 20 & $\leq 3.2$ & 20 \\
${ }^{252} \mathrm{Cf}$ & 2.8 & 16.7 & $\leq 0.91$ & $\leq 1.9$ \\
$254 \mathrm{Cf}$ & $0.0263^{\mathrm{b}}$ & 80.6 & $0.0914^{\mathrm{b}}$ & 98.9
\end{tabular}

Amount of ${ }^{254}$ cf shipped:

$237 \mathrm{pg}$

$181 \mathrm{pg}$

aeduced from alpha pulse-height analysis.

beduced from gross neutron counts with known corrections.

from the second run (determined from gross neutron counting using the published value of 3.9 neutrons released per ${ }^{254}$ (f fission) ex(ceeds the literature value of 0.078 for the fraction of ${ }^{254}$ Es which Cecays by electron capture to ${ }^{254} \mathrm{Cf}$. The only californium isotopes detected by alpha pulse-height analysiz were ${ }^{250} \mathrm{Cf}$ and ${ }^{254} \mathrm{Cf}$. Valies for ${ }^{249} \mathrm{Cf},{ }^{251} \mathrm{cf}$, and ${ }^{252}$ Cf are limits of detection.

\section{DECA: AND NEUTRON CROSS-SECTION DATA}

The values that we are currently using for transuranium element decay data and for cross-section data in planning irradiation-processing cycles, calculating production forecasts, and assaying products are tabulated in the appendix of ORNL-5415. 1 


\section{FEFERENCES}

1. I. J. King, J. E. Bigelow, and E. D. Collins, Transuranium Processing Plant Semiannual Report of Production, Status, and Plans for Period Ending December 31, 1977. ORNL-5415 (August 1978).

2. L. J. King, J. E. Bigelow, and E. D. Collins, Transuranium Processing Plant Semiannual Report of Production, Status, and Plans for Period Ending December 31, 1976, ORNL-5305 (October 1977).

3. L. J. King, J. E. Bigelow, and E. D. Collins, Transuranium Processing Plant Semiannual Report of Production, Status, and Plans for Period Ending June 30, 1977, ORNL-5358 (December 1977).

4. L. J. King, J. E. Bigelow, and E. D. Collins, Transuranium Processing Plant Semiannual Report of Production, Status, and Plans for Period Ending December 31, 1975, ORNL-5146 (October 1976).

5. L. J. King, J. E. Bigelow, and E. D. Collins, Transuranium Processing Plant Semiannual feport of Production, Status, and pjins for Period Ending June 30, 1973, ORNL-4921 (March 1974).

6. L. J. King, J. E. Bigelow, and E. D. Collins, Transuranium Processing Plant Semiannual Report of Production, Status, and Plans for Period Ending June 30, 1972, ORNL-4833 (January 1973).

7. L. J. King, J. E. Bigelcr, and E. D. Collins, Transuranium Processing plant Semiannual Report of Production, Status, and Plans for Period Ending June 30, 1976, ORNL-5216 (February 1977). 